Available online at

http://journal.ugm.ac.id/ifnp
INDONESIAN FOOD AND NUTRITION

PROCRESS

Indonesian Food and Nutrition Progress, 2017, Vol. 14, Issue 2

\title{
Commercial, Cooking and Eating Quality Traits and Nutrient Values of Local Mixed Black and White Rice from Yogyakarta Mary Astuti $^{1)^{*}}$, Sri Kanoni ${ }^{1)}$, Mega Mustika ${ }^{1)}$, Oki Krisbianto ${ }^{2)}$
}

\footnotetext{
1) Faculty of Agriculture Technology, Gadjah Mada University, Flora St. 1, Yogyakarta, Indonesia- 55281.

2) Present address: Faculty of Agriculture Technology, Ciputra University, UC Town, Citraland, Surabaya, Indonesia - 60219 .

*) Corresponding author. Tel: +6-285-729-707-222; E-mail: ana_food@yahoo.com.
}

Received 13 October 2017; Accepted 28 December 2017; Published Online 29 November 2017

\begin{abstract}
Black rice has higher anthocyanin content and other nutritional values than white rice but is not preferable as a staple food by Indonesian people especially because of its aroma and texture. Mixing black rice with white rice was expected to increase its cooking and eating qualities but might affect its commercial and nutritional qualities. Local cultivars of black rice Cempo Ireng and white rice Mentik Wangi were mixed at ratios 1:0 (S1), 3:1 (S2), 1:1 (S3), 1:3 (S4) and 0:1 (S5) w/w. The raw and cooked mixed rice were physically, chemically, physicochemically and sensorily analyzed to determine its commercial, cooking, eating and nutritional qualities. The addition of white rice increased the cooking and eating qualities of mixed rice but reduced its nutritional value. It had been suggested that the ratio of black rice and white rice must not lower than 1:1 to preserve its eating and nutritional qualities.
\end{abstract}

Keywords: black rice, mixed rice, cooking quality, eating quality, sensory.

\section{Practical Applications}

The positive effect of black rice for health has been demonstrated. Along with the growing of public awareness for health, especially in Indonesia, the demand for black rice is increasing but has been limited by consumers' acceptance for its texture and flavor. That has become a consideration for consumers especially the diabetic patients to consume black rice as staple food. This study may give useful information for, but are not limited to, health providers, nutritionists, dietitians, general public and patients, and even distributors of mixed black and white rice package.

\section{Introduction}

Diabetes melitus has been known as the mother of disease because it may initiate another metabolic diseases such as hypertension, cardiovascular diseases, kidney failure and blindness (DPPTM, 2008). A research by Wild et al. (2004) found that Indonesia had become the fourth country with the most people with diabetes worldwide. Further research by BPPK (2013) found that Yogyakarta was Indonesian province with the highest prevalence of diabetes which was diagnosed by doctors.

Despite their fondness towards sweet foods such as gudeg, people from Yogyakarta are well aware of their health. One of their efforts is to change their staple food (white 
rice) with pigmented rice, i.e. red or black rice. The potency of black rice to alleviate diabetic or hyperlipidemic symptoms has been demonstrated by some local studies (Fithriyati, 2015; Krisbianto et al., 2016a; Nurrahmawati, 2013; Pratama, 2016). Furthermore, it also has higher nutrient content than red rice cultivars (Ha et al., 1999; Sompong et al., 2011).

Red rice has been known well as healthy food by most Indonesian people, but the same thing does not go for black rice. Some people locally consumed black rice for a very long time, but it had not been widely known until the last decade. Indonesian people often think that black rice is just the same with black waxy (glutinous or sticky) rice. For the information, Indonesian people consume non-waxy rice (beras) as staple while waxy rice (ketan) as cake or snack. Kristamtini (2009) proposed a reason that black rice was once exclusively consumed only by the royal family of Surakarta Sultanate.

Black rice, the same as red rice, is neither common nor preferable staple for Indonesian people. The price is 2-3 times higher than red or white rice, the texture is relatively hard and more perishable than white rice. Furthermore, its aroma is strong but different than white rice and not suitable to go with most of Indonesian side dishes. The aroma clearly resembles black waxy rice which is usually eaten with sugar and coconut milk. Ratnaningsih (2010) applied it to

Yogyakarta traditional snacks and cakes but it won't be eaten daily. As daily staple food, people often mixed black rice with white rice by certain but different ratios depend on their appetite. This study was to evaluate the different ratios of black and white on the commercial quality, cooking quality and eating quality of mixed rice. The rice cultivars were selected from the local cultivars from Yogyakarta, i.e. Cempo Ireng and Mentik Wangi. Both cultivars are known by a local collective name as Pari Jowo (Javanese Paddy) because it has been cultivated before the Green Revolution and the introduction of new paddy cultivars to Indonesian farmers. MentikWangi is a cultivar of white rice, known by its fragrant aroma, and had been recorded on early $19^{\text {th }}$ Century Javanese literature Serat Centhini (Ranggasutrasna et al., 2008).

\section{MATERIALS AND METHODS}

\section{Materials}

Black rice (Oryza sativa cv. Cempo Ireng) was purchased from Lumpang Community, Yogyakarta, Indonesia. Polished aromatic white rice (Oryza sativa cv. Mentik Wangi) was purchased from Salam farmland, Magelang, Indonesia. All chemicals and reagents were from Merck Milipore and kindly provided by Food Chemical and Biochemical Laboratory, Faculty of Agriculture Technology, Gadjah Mada University, Yogyakarta, Indonesia.

\section{Sample Preparation}

Black rice and white rice were mixed at ratios 1:0 (S1), 3:1 (S2), 1:1 (S3), 1:3 (S4) and $0: 1$ (S5) w/w. A total of $50 \mathrm{~g}$ mixed rice samples each were washed and then cooked in rice cooker (National SR-WO6N) with the addition of $150 \mathrm{ml}$ water for 20-25 minutes.

\section{Physical Analysis}

Head Rice Yield (HRY), Broken Rice Yield (BRY) and Small Broken or Brewers Rice Yield (SRY) analyses were based on Indonesian National Standard (SNI) 6128:2008 (BSN, 2008). Head rice, broken rice, and small broken rice grains from a total of $100 \mathrm{~g}$ of rice sample were manually separated using tweezers and then weighed. The percentage of HRY, BRY and SRY were calculated by divided each weight by total weight (100 g) and then multiplied by $100 \%$.

For color analysis, a total of $100 \mathrm{~g}$ mixed rice samples each were grinded by dry grinder 
(BL-301 GS G/Y) and sieved through 60 mesh size stainless wire sieve. The powders were analyzed using Lovibond Tintometer.

\section{Chemical Analysis}

Moisture content (\%) was based on gravimetric method by AOAC Official Method 931.04. Protein content (\%) was determined by Micro-Kjeldahl method which was described on AOAC Official Method 960.52 with a slight modification on the catalyst. The catalyst was based on Sudarmadji et al. (2010) with the ratio of $\mathrm{Na}_{2} \mathrm{SO}_{4}:$ Se : $\mathrm{CuSO}_{4}=250$ : 0.7 : 5. Fat content (\%) was estimated by Petroleum Ether extraction method based on Sudarmadji et al. (2010).

\section{Physicochemical Analysis \\ Volume Expansion Ratio (VER)}

The method was described by Chukwuemeka et al. (2015) with some modifications. The volume of raw rice was calculated by subtracting the total volume of $50 \mathrm{~g}$ raw rice and initial water $(150 \mathrm{ml})$ with $150 \mathrm{ml}$. The volume of cooked rice was calculated by subtracting the total volume of cooked rice and additional water $(250 \mathrm{ml})$ with $250 \mathrm{ml}$. VER (\%v/v) was calculated as follow: cooked rice volume ( $\mathrm{ml}$ ) was divided by raw rice volume $(\mathrm{ml})$ and then multiplied by $100 \%$.

\section{Water Absorption Capacity (WAC)}

The absorbed water weight (g) was calculated by subtracting the cooked rice weight $(\mathrm{g})$ with the initial raw rice weight (50 g). WAC (\%w/w) was calculated as follow: absorbed water weight $(\mathrm{g})$ was divided by initial raw rice weight $(50 \mathrm{~g})$ and then multiplied by $100 \%$.

\section{Gel Consistency (GC) and Alkali Spreading Value (ASV)}

The methods for GC and ASV were described by Nadaf et al. (2015).

\section{Sensory Evaluation}

Sensory evaluation was conducted by a panel group consist of eight semi-trained panelists. Quantitative affective method (acceptance test) was used to evaluate the attributes of samples (texture, color and aroma) by using intensity scale of 1 to 5 (Meilgaard et al., 2000). The previous test was followed by a focus group discussion (qualitative affective method) to access the perspective of panel group's members (Meilgaard et al., 2000; Wong, 2008).

\section{Statistical analysis}

The data was subjected to be analyzed statistically using One-Way ANOVA (analysis of variance) followed by Duncan's New Multiple Range Test (DMRT) at the 95\% confidence level to determine differences between treatments. Both were using SPSS 16.0 (SPSS, Inc., Chicago, IL, USA).

\section{RESULTS AND DISCUSSION}

\section{Commercial Quality}

Commercial quality is determined by the physical appearance of rice grains, named after it's highly importance on rice trading than other qualities of rice. SNI has set 10 quality components for the specification of rice commercial quality requirement (BSN, 2008). We only analyzed 5 of

them (Table 1 and Figure 1) for some definite reasons, i.e. that black rice is unpolished and still colored, while the specification from SNI is basically for polished white rice.

As noted below, black rice was unpolished thus still have its bran layer. On the other hand, polishing process used friction force to remove the bran layer from rice kernel but may also cause the grains broken. This explained why the percentages of broken and small broken rice of white rice (S5) were higher than black rice (S1). The higher ratio of black rice on mixed rice samples definitely reduced its broken and small broken grains 
thus increased its commercial quality. It can be seen in Table 1 that S3 and S4 were on the same commercial quality grade as S5 (Grade 2 based on $\mathrm{SNI}$ ) while the moisture content was not significantly different between the samples. As defined by SNI, the maximum moisture content for Grade 1 to 4 is $14 \%$ (BSN, 2008).

Table 1. Commercial quality of mixed rice samples

\begin{tabular}{llllll}
\hline Sampel & $\begin{array}{l}\text { Moisture } \\
\text { Content }(\%)\end{array}$ & $\begin{array}{l}\text { Head Rice } \\
(\% \mathrm{w} / \mathrm{w}), \mathrm{SD}\end{array}$ & $\begin{array}{l}\text { Broken Rice } \\
(\% \mathrm{w} / \mathrm{w}), \mathrm{SD}\end{array}$ & $\begin{array}{l}\text { Small Broken } \\
\text { Rice }(\% \mathrm{w} / \mathrm{w}),\end{array}$ & $\begin{array}{l}\text { Rice Quality } \\
\text { based on SNI } \\
\end{array}$ \\
& & & SD & $6128: 2008$ \\
\hline S1 & $13.07(0.12)^{\mathrm{a}}$ & $91.48(0.13)^{\mathrm{b}}$ & $7.83(0.32)^{\mathrm{b}}$ & $0.69(0.20)^{\mathrm{c}}$ & 5 \\
S2 & $13.16(0.28)^{\mathrm{a}}$ & $90.92(0.63)^{\mathrm{b}}$ & $8.22(0.68)^{\mathrm{b}}$ & $0.86(0.05)^{\mathrm{c}}$ & 3 \\
S3 & $13.23(0.91)^{\mathrm{a}}$ & $90.01(0.58)^{\mathrm{b}}$ & $9.05(0.52)^{\mathrm{b}}$ & $0.94(0.06)^{\mathrm{c}}$ & 2 \\
S4 & $13.51(0.39)^{\mathrm{a}}$ & $83.74(1.38)^{\mathrm{b}}$ & $14.90(1.58)^{\mathrm{b}}$ & $1.36(0.21)^{\mathrm{b}}$ & 2 \\
S5 & $13.52(0.50)^{\mathrm{a}}$ & $68.53(9.64)^{\mathrm{a}}$ & $29.00(9.81)^{\mathrm{a}}$ & $2.47(0.16)^{\mathrm{a}}$ & 2
\end{tabular}

Mean (SD) values followed by the same letter in each column are not significantly different at $P<0.05$ by ANOVA and DMRT. The grade of commercial quality based on SNI 6128:2008 are from 1 (best quality) to 5 (poor quality).

Based on the yellowish color of the white rice grain, it could be concluded that the white rice sample had degrees of milling (DOM) lower than 100\%. Figure 1 shows that S5 still had low yellow and red colors but undetected blue color. Lamberts et al. (2007) found that the core of rice grains contain less red and yellow colors than the surface. It is likely because most local farmers only use conventional polishing machine without mist sprayer method. Furthermore, Mentik Wangi cultivar has been known to be fragrant but not white in color, unlike Mentik Susu and the hybrid of both previous cultivars, i.e. Mentik Wangi Susu.

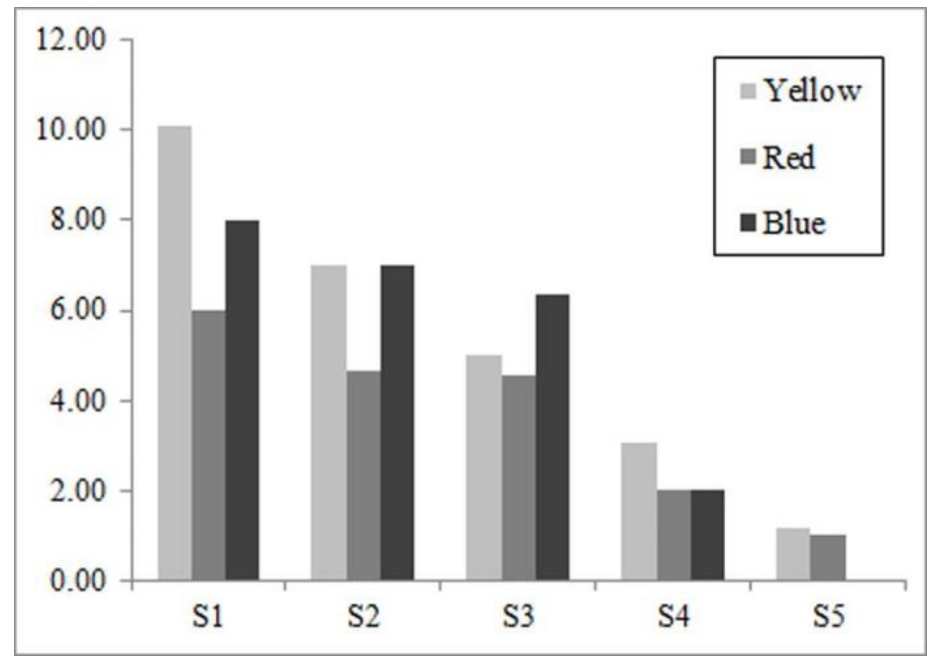

Fig. 1. Color characteristic of mixed rice samples

As expected, the higher ratio of black rice on mixed rice samples increased its yellow, red and blue colors. Black rice contains a high level of anthocyanin pigment on its bran, especially aleurone layer, which is high in antioxidant capacity (Krisbianto et al., 
2016a; Park et al., 2008). The color was described as blackish old purple by Shinta et al. (2014). Unlike the specification quality for white rice that regards red rice grains as impurities and may lower its grade, darker color of black rice is preferable because it contains higher anthocyanin pigment (Kristamtini et al., 2014). Commercial quality never stands alone in influencing the selling price of rice, but also the cooking and eating quality. Nutrient values have always been a minor factor for white rice, but may affect black rice selling price a lot.

\section{Cooking Quality}

The physicochemical properties of rice were highly dependent on its amylose: amylopectin ratio and were used to determine its cooking quality. The ratio of amylose: amylopectin influences the water absorption, volume expansion and the texture of cooked rice, but gel consistency appears only affected by its amylopectin content hence influenced its eating quality (Singhal et al., 1997). Bhat and Riar (2016) found that the cooking of rice was positively correlated with amylopectin content but negatively correlated with amylose content. Based on Kristamtini et al. (2011), Mentik Wangi contained about 15-
$16 \%$ amylose and $35-42 \%$ amylopectin. Mutters and Thompson (2009) classified it as low amylose content (10-20\%), rather soft and moist than cooked rice with higher amylose content because of its tendency to retrograde than amylopectin.

Higher ratio of black rice reduced VER and WAC of samples as shown in Table 2. Lamberts et al. (2007) found that rice starch was concentrated in the core while protein in the outer layer of endosperm. Mizuma (2014) stated that polishing process increases the starch content of rice grains which is absorbed more water than protein, while only $20 \%$ of rice protein is water soluble (Rimbawan, 2007). Furthermore, the bran layer of rice grains is high in minerals, fat and protein which may inhibit water absorption during cooking (Lamberts et al., 2007; Mizuma, 2014). This finding was supported by Ayabe et al. (2014) who found that water absorption rate of black rice was lower than polished rice. Lower water absorption rate and the firm structure of bran layer were likely inhibiting the volume expansion by starch gelatinization thus increasing the hardness of cooked rice. Bhat and Riar (2016) found that VER positively correlated with hardness.

Table 2. Cooking quality of mixed rice samples.

\begin{tabular}{llllll}
\hline Sampel & VER $(\% \mathrm{v} / \mathrm{v})$, SD & WAC $(\% \mathrm{w} / \mathrm{w}), \mathrm{SD}$ & $\mathrm{GC}(\mathrm{mm}), \mathrm{SD}$ & ASV, SD & PCR (\%db) \\
\hline S1 & $125.96(0.18)^{\mathrm{e}}$ & $127.70(0.01)^{\mathrm{e}}$ & $53.50(2.12)^{\mathrm{c}}$ & $2.00(0.00)^{\mathrm{c}}$ & $9.75(0.72)^{\mathrm{a}}$ \\
S2 & $173.29(1.40)^{\mathrm{d}}$ & $174.00(0.12)^{\mathrm{d}}$ & $56.00(1.41)^{\mathrm{bc}}$ & $2.50(0.71)^{\mathrm{c}}$ & $9.52(0.00)^{\mathrm{a}}$ \\
S3 & $235.00(1.92)^{\mathrm{c}}$ & $208.94(0.00)^{\mathrm{c}}$ & $65.50(7.78)^{\mathrm{ab}}$ & $4.50(0.71)^{\mathrm{b}}$ & $9.14(0.00)^{\mathrm{a}}$ \\
S4 & $260.72(4.13)^{\mathrm{b}}$ & $249.34(0.01)^{\mathrm{b}}$ & $66.00(1.41)^{\mathrm{a}}$ & $5.50(0.71)^{\mathrm{b}}$ & $8.85(0.00)^{\mathrm{a}}$ \\
S5 & $304.76(6.73)^{\mathrm{a}}$ & $267.67(0.01)^{\mathrm{a}}$ & $70.00(1.41)^{\mathrm{a}}$ & $7.00(0.00)^{\mathrm{a}}$ & $8.53(0.94)^{\mathrm{a}}$ \\
\hline
\end{tabular}

Mean (SD) values followed by the same letter in each column are not significant different at $P<0.05$ by ANOVA and DMRT. VER = Volume Expansion Ratio; $W A C=$ Water Absorption Capacity; GC = Gel Consistency; ASV = Alkali Spreading Value. PCR = Protein Content of Raw Rice. $\% \mathrm{db}=\%$ dry basis. 
2). This characteristic is used as a criterion by many food manufacturers to selecting their raw materials (Mutters and Thompson, 2009). By the three types of gel consistency described by Juliano and Villareal (1993), S1 and S2 had medium (41-60 mm) while S3, S4 and $\mathrm{S} 5$ had soft $(61-100 \mathrm{~mm})$ gel consistency. The result had shown that the addition of $50 \%$ white rice to the mixed rice sample able to reduce its gel hardness which was not significantly different from S4 and S5. GC value connected with the physical appearance of cooked rice, as rice with high GC value tends to be less sticky and hard (Mutters and Thompson, 2009).

Protein content of raw rice is negatively correlated with ASV. Rice with higher protein content requires longer cooking time and increases its hardness. ASV determines gelatinization temperature of starch hence the time requires for cooking (Mutters and Thompson, 2009). ASV was rated by seven points scale as described by Juliano and
Villareal (1993) and served in Table 2 along with protein content of raw rice. Black rice (Cempo Ireng) had higher but insignificantly different of protein content than white rice (Mentik Wangi) but the ASV was significantly lower. S1 and S2 were classified as high final gelatinization temperature $\left(74.5-80^{\circ} \mathrm{C}\right), \mathrm{S} 3$ as intermediate $\left(70-74^{\circ} \mathrm{C}\right)$, while $\mathrm{S} 4$ and $\mathrm{S} 5$ as low $\left(55-69^{\circ} \mathrm{C}\right)$. Damardjati (1987) stated that higher gelatinization temperature leads to longer cooking time, required more water for cooking and lower VER, which is supported our finding.

\section{Eating Quality of Cooked Rice}

Eating quality of cooked rice is closely related to its cooking quality as stated by Sattari et al. (2015), except that cooking quality use human perception as its measuring instrument. Figure 2 shows three sensory measurements of mixed rice samples by a group of panelists in this study.

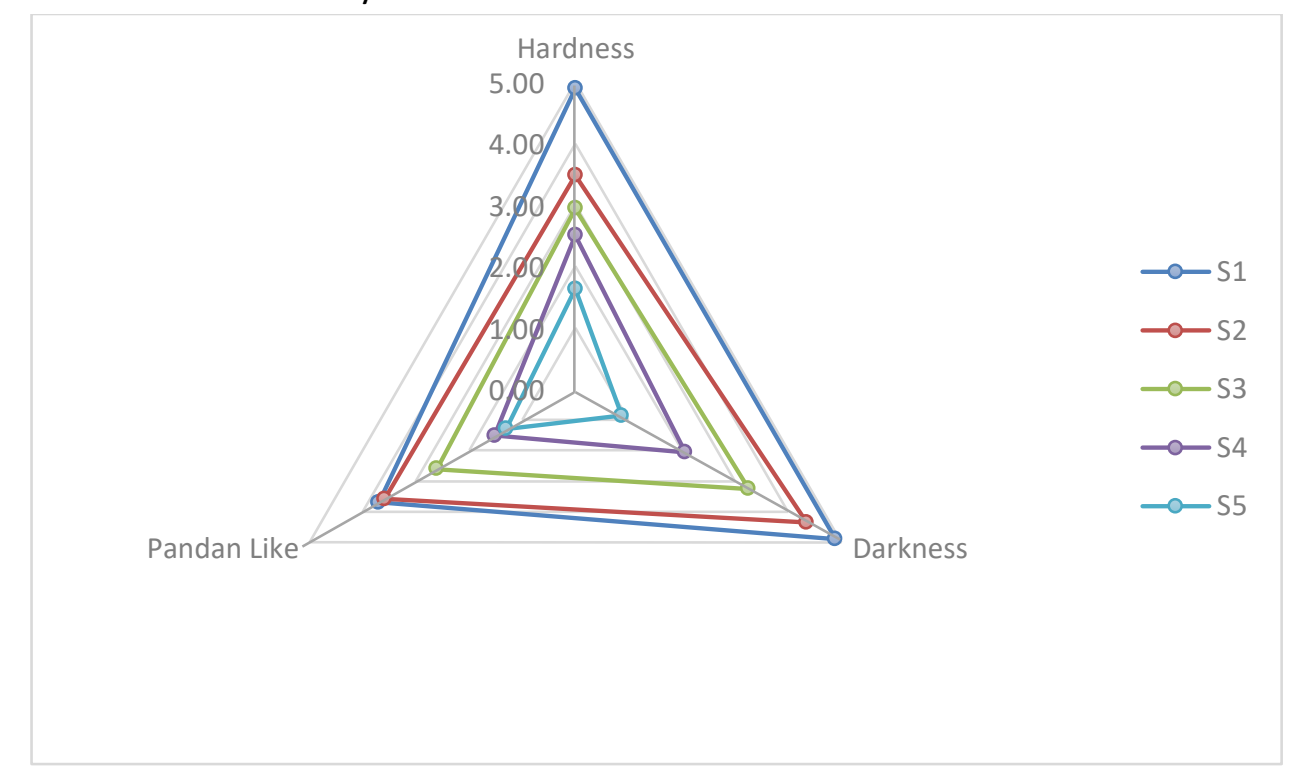

Fig. 2. Sensory characteristic of cooked mixed rice samples on the scale of 1 (very mild) to 5 (very intense). Texture data was previously published on Krisbianto et al. (2016b).

Higher ratio of black rice lead to higher intensity of texture hardness and darker color had been demonstrated. As previously discussed, higher ratios of black rice resulted in lower VER, WAC, GC and ASV but higher protein content of mixed rice. This founding was supported by the evaluation of its eating quality. Kohyama et al. (2016) stated that amylose content was a major factor influencing rice texture and early mastication 
stage. Singhal et al. (1997) explained that eating quality had a positive correlation with amylose content of rice as flaky and non-waxy cooked rice had higher eating quality. But harder texture was undesirable by consumers. As previously reported by Krisbianto et al. (2016b), the ratio of black rice: white rice $=$ 1:1 (S3) was the most preferred by panelists.

Cooked S4 (ratio of black rice: white rice $=1: 3$ ) sample was the most undesirable for its gritty texture because the texture of black rice part was harder than the white rice part. Most of panelists commented that S4 gave mouth feel like cooked rice full of sand impurities. Particularly, its color uniformity, faded purple color with dark spots, was very undesirable by all panelists in group, as previously reported in Krisbianto et al. (2016b).

Lastly, black rice cultivar Cempo Ireng and white rice cultivar Mentik Wangi had strongly delicious but different aroma. Black rice fragrant and sweet aroma was suitable for cake while white rice Mentik Wangi pandan-like mild aroma was suitable for Indonesian side dishes had been previously noted. This pandan-like (or popcorn-like) aroma characteristic of rice is principally regarded to 2-acetyl-1-pyrroline (2AP) which is contained in high amount in both aromatic and black rice cultivars (Yang et al., 2008b).
This compound, along with some aldehydes, alcohols and cyclic compounds, contributes the aroma of rice (Khammari et al., 2016). The distinctive aroma compounds of black rice were identified as $2 \mathrm{AP}$, guaiacol, toluene and 4-vinylguaiacol; 2AP and guaiacol were affirmed as the critical aroma compounds (Yang et al., 2008a). The higher ratio of white rice reduced the aroma of black rice which made it more suitable to be eaten as staple food for Indonesian population. Some panelists identified bitter aftertaste on S1 and S2. Bett-Garber et al. (2012) noted that darker rice cultivars have more bitter taste and astringency because of its phenolic content, and its flavor was described as oily, darkberry, medicinal and smoky.

\section{Nutrients}

Polishing process reduced protein and fat, minerals but increased starch content had previously been mentioned. On the other hand, nutrient quality is often not in a positive correlation with the other three previous qualities of rice (Rimbawan, 2007). It has been shown in Table 3 that the addition of white rice had reduced the protein and fat content of cooked mixed rice, while the higher ratio of black rice reduced cooking and eating quality had been demonstrated.

Table 3. Protein and fat content of cooked mixed rice samples.

\begin{tabular}{ccc}
\hline Sampel & Protein $(\% \mathrm{db})$, SD & Fat $(\% \mathrm{db})$, SD \\
\hline S1 & $8.98(0.13)^{\mathrm{a}}$ & $0.28(0.06)^{\mathrm{b}}$ \\
S2 & $8.48(0.09)^{\mathrm{a}}$ & $0.11(0.01)^{\mathrm{a}}$ \\
S3 & $8.55(0.19)^{\mathrm{a}}$ & $0.07(0.04)^{\mathrm{a}}$ \\
S4 & $7.88(1.87)^{\mathrm{a}}$ & $0.06(0.03)^{\mathrm{a}}$ \\
S5 & $7.26(0.21)^{\mathrm{a}}$ & $0.03(0.02)^{\mathrm{a}}$
\end{tabular}

Mean (SD) values followed by the same letter in each column are not significant different at $P<0.05$ by ANOVA and DMRT. 
Black rice has been known as functional food hence its nutrients and anthocyanin content get more attention than white rice cultivars. Mixing black rice with white rice to increase its eating quality has led to another problem of decreasing its nutrient quality, especially its antioxidant properties. Kong and Lee (2010) reported that high level of antioxidant compounds were found in the bran fraction of rice and only relatively small amount was found in endosperm fraction. Monika et al. (2013) also reported that polished white rice had a very low antioxidant properties compared to colored rice samples. In addition, Krisbianto et al (2016b) and Saikia et al. (2012) demonstrated that cooking process highly reduced antioxidant content and capacity of all rice. Nevertheless, the antioxidant properties of mixed rice from this study was done by Krisbianto et al (2016b) and found that cooked mixed rice still had its antioxidant activity.

\section{Conclusion}

Addition of white rice to black rice was proven to increase its cooking and eating qualities, but reduced its nutritional value. It had been suggested that the ratio of black rice: white rice must not lower than 1:1 or it would terribly reduce the nutrient quality of mixed rice, but also had unappealing appearance and unpleasant mouth feel. Higher ratio of black rice should also becarefully considered because it would reduce the cooking and eating quality of mixed rice, especially increase the hardness and aroma intensity of black rice to the mixed rice.

\section{References}

Ayabe, S., Wada, N., Oishi, K., and Kasai, M. 2014. Changes in the physicochemical properties of black rice upon cooking. 日本 調理科学会誌 47, 76-83.
Bett-Garber, K.L., Lea, J.M., Champagne, E.T., and McClung, A.M. 2012. Whole-grain rice flavor associated with assorted bran colors. J. Sens. Stud. 27, 78-86.

Bhat, F.M. and Riar, C.S. 2016. Physicochemical, cooking and textural characteristics of grains of different rice (Oryza sativa L.) cultivars of temperate region of India and their interrelationships.

J. Texture Stud. 'Accepted Article', doi: 10.1111/jtxs.12227.

BPPK (Badan Penelitian dan Pengembangan Kesehatan). 2013. Riset Kesehatan Dasar 2013, Kementerian Kesehatan Republik Indonesia, Jakarta.

BSN (Badan Standarisasi Nasional). (2008). SNI 6128:2008 : Beras, Badan Standarisasi Nasional, Jakarta.

Chukwuemeka, A.I., Kelechi, A.J., and Bernard, A. 2015. Cooking and Physicochemical properties of five rice varieties produced in Ohaukwu local government area. Eur. J. Food Sci. Technol. 3, 1-10.

Damardjati, D.S. 1987. Prospek peningkatan mutu beras di Indonesia. J. Litbang. Pertanian 6, 85-94.

DPPTM (Direktorat Pengendalian Penyakit Tidak Menular). 2008. Pedoman Pengendalian Diabetes Melitus dan Penyakit Metabolik, Departemen Kesehatan Republik Indonesia, Jakarta.

Fithriyati, M.N.C. 2015. Perbandingan efek anti inflamasi antara ekstrak antosianin beras hitam (Oryza sativa L.) dan ubi jalar ungu (Ipomea batatas poiret) pada tikus Diabetes Mellitus Tipe 2. Thesis, Faculty of Agriculture Technology, Gadjah Mada University, Yogyakarta.

Ha, T.Y., Park, S.H., Lee, C.H., and Lee, S.H. 1999. Chemical composition of pigmented rice varieties. Korean J. Food Sci. Technol. 31, 336-341.

Juliano, B.O. and Villareal, C.P. 1993. Grain Quality Evaluation of World Rices, pp. 7-9, International Rice Research Institute, 
Manila.

Khammari, M., Khani, M.A.M, Khammari, D.A., and Nia, M.O.R. 2016. The eating and cooking qualities of rice: a review. IJSRST 2, 134-139.

Kohyama, K., Sodhi, N.S., Suzuki, K., and Sasaki, T. 2016. Texture evaluation of cooked rice prepared from Japanese cultivars using two-bite instrumental test and electromyography. J. Texture Stud. 47, 188-198.

Krisbianto, O., Astuti, M., and Marsono, Y. 2016a. Antihyperglycemic effect and antioxidants properties of black rice (Oryza sativa L. indica) cereal and anthocyanin extract on health and histopathology of hyperglycemic rats. Pak. J. Nutr. 15, 702707.

Krisbianto, O., Mustika, M., and Astuti, M. 2016b. Black and white rice ratio on sensory and antioxidant activity of steamed rice. Conference paper presented at "International Food Conference 2016" held at Widya Mandala Catholic University, Surabaya, Indonesia (20-21 October 2016).

Kristamtini. 2009. Mengenal beras hitam dari Bantul, Tabloid Sinar Tani (13 May 2009). Kristamtini, Widyayanti, S., and Rahayu, S. 2011, Respon padi lokal Mentik Wangi terhadap pendekatan teknologi SRI (System of Rice Intensification) dan PTT (Pengelolaan Tanaman Terpadu). Widyariset 14, 565-570.

Kristamtini, Taryono, Basunanda, P., and Murti, R.H. 2014. Keragaman genetik dan korelasi parameter warna beras dan kandungan antosianin total sebelas kultivar padi beras hitam lokal. Ilmu Pertanian 17, 57-70.

Kong, S. and Lee, J. 2010. Antioxidants in milling fractions of black rice cultivars. Food Chem. 120, 278-281.

Lamberts, L., Bie, E.D., Vandeputte, G.E., Veraverbeke, W.S., Derycke, V., Man, W.D., Delcour, J.A. 2007. Effect of milling on colour and nutritional properties of rice. Food Chem. 100, 1496-1503.

Meilgaard, M., Civille, G.V., and Carr, B.T. 2000. Sensory Evaluation Techniques, 3rd Ed., Chapter 5 and 12, CRC Press, Boca Raton.

Mizuma, T. 2014. Effects of the rice polishing ratio on water absorption of rice. 関西福祉科学大学紀要18, 33-39.

Monika, P., Saputrajaya, W., Liguori, C., Widyawati, P.S., Suteja, A.M., and T.I.P. Suseno, 2013. Aktivitas antioksidan beras organik varietas lokal (Putih Varietas Cianjur, Merah Varietas Saodah, Hitam Varietas Jawa). Conference paper presented at "Seminar Nasional:

Menggagas Kebangkitan Komoditas Unggulan Lokal Pertanian dan Kelautan" held at Trunojoyo University, Madura, Indonesia (June 2013).

Mutters, R.G. and Thompson, J.F. 2009. Rice Quality Handbook, pp. 12-13, UCANR Publications, California.

Nadaf, A., Mathure, S., and Jawali, N. 2015. Scented Rice (Oryza sativa L.) Cultivars of India: A Perspective on Quality and Diversity, pp. 35, Springer, New Delhi.

Nurrahmawati, N. 2013. The effect of rice (Oryza sativa L.) cultivars Cempo Ireng, Cempo Abang, and IR-64 on histological structure of hyperlipidemic albino rat's liver and kidney (Rattus norvegicus Berkenhout, 1769). Faculty of Biology, Gadjah Mada University, Yogyakarta.

Park, Y.S., Kim, S.J., and Chang, H.I. 2008. Isolation of anthocyanin from black rice (Heugjinjubyeo) and screening of its antioxidant activities. Kor. J. Microbiol. Biotechnol. 36, 55-60.

Pratama, A. 2016. Perbandingan efektivitas antioksidan antosianin ubi jalar ungu (Ipomoea batatas L.), beras hitam (oryza sativa L.) dan beras ketan hitam (Oryza sativa F.) terhadap perbaikan glukosa darah, status antioksidan, serta profil lipid 
pada tikus hiperglikemia. Thesis, Faculty of Agriculture Technology, Gadjah Mada University, Yogyakarta.

Ranggasutrasna, Yasadipura II, and Sastradipura. 2008. Centhini Tambangraras-Amongraga 3, pp. 314, Balai Pustaka, Jakarta.

Ratnaningsih, N. 2010. Ringkasan potensi beras hitam sebagai sumber antosianin dan aplikasinya pada makanan tradisional Yogyakarta. Research, Lembaga Penelitian dan Pengabdian kepada Masyarakat, Gadjah Mada University, Yogyakarta.

Rimbawan. 2007. Pengembangan teknologi pengolahan beras rendah indeks glisemik. Pangan 48/XVI/Januari/2007, 70-75.

Saikia, S., Dutta, H., Saikia, D., and Mahanta, C.L. 2012. Quality characterisation and estimation of phytochemicals content and antioxidant capacity of aromatic pigmented and non-pigmented rice varieties. Food Res. Int. 46, 334-340.

Sattari, A., Mahdinezhad, N., Fakheri, B., Noroozi, M., and Beheshtizadeh, H. 2015. Improvement of eating and cooking qualities of rice: a review. Int. J. Farm. \& Alli. Sci. 4, 153-160.

Shinta, Indriyani, S., and Arisoesilaningsih, E. 2014. Morphological variation of six pigmented rice local varieties grown in organic rice field in Sengguruh Village, Kepanjen District, Malang Regency. J. Trop.
Life Sci. 4, 149-150.

Singhal, R., Kulkarni, P.R., and Rege, D.V. 1997. Handbook of Indices of Food Quality and Authenticity, pp. 57-58, Woodhead Publishing, Cambridge.

Sompong, R., Siebenhandl-Ehn, S., LinsbergerMartin, G., and Berghofer, E. 2011. Physicochemical and antioxidative properties of red and black rice varieties from Thailand, China and Sri Lanka. Food Chem. 124, 132-140.

Sudarmadji, S. Haryono, B., and Suhardi. 2010. Analisa Bahan Makanan dan Pertanian, $2^{\text {nd }}$ Ed., Liberty, Yogyakarta.

Wild, S., Roglic, G., Green, A., Sicree, R., and King, H. 2004. Global prevelance of diabetes: estimates for the year 2000 and projections for 2030. Diabetes Care 27, 1047-1053.

Wong, L.P. 2008. Focus group discussion: a tool for health and medical research. Singapore Med. J. 49, 256-261.

Yanga , D.S., Lee, K.S., Jeong, O.Y., Kim, K.J., and Kays, S.J. Characterization of volatile aroma compounds in cooked black rice. J. Agric. Food Chem. 56, 235-240.

Yang ${ }^{b}$, D.S., Shewfelt, R.L., Lee, K.S., and Kays, S.J. 2008. Comparison of odor-active compounds from six distinctly different rice flavor types. J. Agric. Food Chem. 56, 2780-2787. 